\title{
Pengembangan Koperasi Simpan Pinjam Berbasis Teknologi Informasi pada Koperasi Simpan Pinjam Jaya Makmur
}

\author{
Nurjayadi $^{1 *}$, Herwin ${ }^{2}$, Khusaeri Andesa ${ }^{3}$, Torkis Nasution ${ }^{4}$ \\ ${ }^{123}$ Manajemen Informatika, STMIK Amik Riau \\ ${ }^{4}$ Teknik Informatika, STMIK Amik Riau \\ email: nurjayadi@sar.ac.id
}

\begin{abstract}
The Savings and Loans Cooperative is under the management of BUMDes Jaya Makmur and is engaged in a productive economy. The problems are the Ability of Financial Bookkeeping, Financial Governance, Low Public Interest. The field of financial accounting, namely how to improve the ability of employees to do financial bookkeeping. The solution taken is a common understanding of the need for a bookkeeping system in KSP management, providing financial system training for employees, providing assistance. The field of financial governance, namely how to implement information technology to implement financial governance. The solution is to install financial applications, provide training on the use of KSP financial applications, implement financial applications, assist in the use of applications. Areas of increasing public interest, namely How to increase public interest in borrowing and saving money to BUMDes Savings and Loans, the solution given is a common understanding of the use of technology, implementation of a transparent financial system, assistance in implementing the membership system. The use of information technology in the management of KSP increases productivity and efficiency of performance and governance, increases member satisfaction, increases transparency, and better management accountability.
\end{abstract}

Keywords: save widtrow, BUMDes, information technology, development

\begin{abstract}
Abstrak
Koperasi Simpan Pinjam berada di bawah pengelolaan BUMDes Jaya Makmur bergerak dalam bidang ekonomi produktif. Permasalahan adalah Kemampuan Pembukuan Keuangan, Tata Kelola Keuangan, Minat Masyarakat Rendah. Bidang pembukuan keuangan, yaitu Bagaimana meningkatkan kemampuan pegawai dalam melakukan pembukuan keuangan. Solusi yang dilakukan adalah penyamaan pemahaman perlunya sistem pembukuan dalam pengelolaan KSP, memberikan pelatihan sistem keuangan bagi pegawai, melakukan pendampingan. Bidang tata kelola keuangan, yaitu Bagaimana mengimplementasikan teknologi informasi untuk melaksanakan tata kelola keuangan. Solusinya yang dilakukan adalah instalasi aplikasi keuangan, memberikan pelatihan penggunaan aplikasi keuangan KSP, implementasi aplikasi keuangan, pendampingan penggunaan aplikasi. Bidang peningkatan minat masyarakat, yaitu Bagaimana meningkatkan minat masyarakat untuk meminjam dan menyimpan uang ke Simpan Pinjam BUMDes, solusi yang diberikan adalah penyamaan pemahaman dalam pemanfaatan teknologi, implementasi sistem keuangan yang transparan, pendampingan pelaksanaan sistem keanggotaan. Pemanfaatan teknologi informasi dalam pengelolaan KSP meningkatkan produktivitas dan efisiensi kinerja dan tata kelola, peningkatan kepuasan anggota, meningkatnya transparansi, dan akuntabilitas pengelolaan yang lebih baik.
\end{abstract}

Kata Kunci : simpan pinjam, BUMDes, teknologi informasi, pengembangan

\section{PENDAHULUAN}

Pedoman bagi daerah dan desa dalam pembentukan dan pengelolaan BUMDes Badan Usaha Milik Desa (BUMDes) yaitu

doi: https://doi.org/10.37859/jpumri.v4i2.2221 mengacu pada Permendesa Nomor 4 Tahun 2015 tentang Pendirian, Pengurusan dan Pengelolaan, dan Pembubaran Badan Usaha Milik Desa [1]. Sekretaris Jenderal Kementerian Desa, Pembangunan Daerah 
Tertinggal, dan Transmigrasi (Kemendes PDTT) Anwar Sanusi mengatakan hingga Desember 2018, 61\% desa telah memiliki BUMDes atau terbentuk 45.549 unit BUMDes di Indonesia. Permasalahan yang dialami oleh desa adalah: (1) Tidak ada pemahaman bersama; (2) Tidak memahami konsep, tugas, dan kewenangan BUMDes; (3) Tidak ada tata kelola dan akuntabilitas yang baik; (4) Tidak memahami tata cara pembukuan yang baik; (5) Minat masyarakat rendah. Akumulasi permasalahan yang ada di dalam internal BUMDes, menyebabkan penurunan minat masyarakat untuk bertransaksi dengan BUMDes dalam hal ini melakukan penyimpanan dan peminjaman rendah. Dalam hal pelaksanaan pembukuan keuangan, belum tersedia perangkat yang dapat digunakan secara otomatis, pada saat ini masih menggunaan kertas sebagai media pencatatan semua transaksi keuangan. Dalam proses keberlanjutkan kepemimpinan dalam BUMDes, tersirat adanya trauma bagi pejabat baru dalam melakukan terobosan, bahkan menjalankan organisasi yang sudah ada. Sebagaimana di sampaikan oleh Kepala Desa, Bapak Rustamaji SH, hanya sebagian kecil masyarakat yang bersedia untuk perperan serta dalam pengelolaan BUMDes, padahal diperlukan generasi muda untuk dapat menampilkan sosok BUMDes yang dapat diterima oleh masyarakat. Kepala Desa menyampai-kan bahwa kemampuan manajerial dari pegawai yang ada masih lemah dan perlu perbaikan serta dukungan dengan cara implementasi teknologi dan informasi. Struktur organisasi BUMDes Jaya Makmur di tunjukkan pada gambar 1. memang belum diberikan nama oleh desa. Upaya pemerintahan desa dalam menciptakan inkubasi ekonomi terus dilakukan, dengan memberikan akses pembiayaan melalui pembentukan komperasi. Koperasi diharapkan [2] menjadi inkubasi ekonomi bagi maysaraka

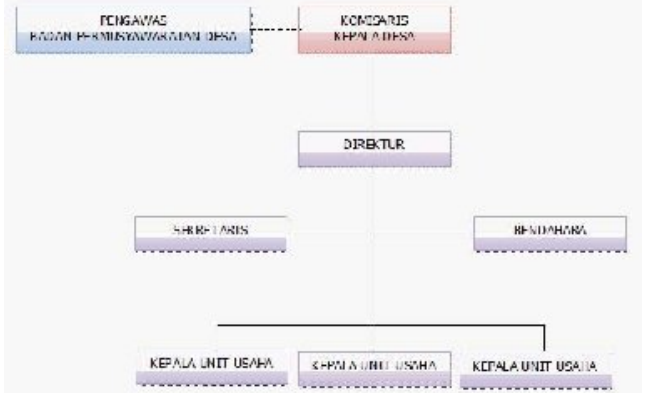

Gambar 1. Struktur Organisasi BUMDes Jaya Makmur

Kantor BUMDes berada di dalam Kantor Desa Rimba Makmur, TIM PPDM telah melakukan kegiatan bersama dengan aparatur desa, Direktur BUMDes, ditunjukkan pada gambar 2 .

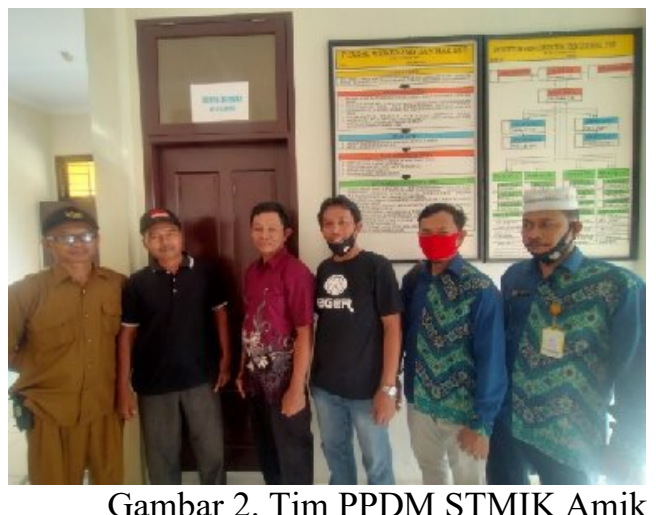

Riau berfoto bersama aparatur desa di depan Kantor BUMDes, kiri ke kanan Sekretaris Desa Sentot Wiyono, Kaur Pemerintahan Suanto, Direktur BUMDes Mujiono, Tim PPDM STMIK Amik Riau Nurjayadi, M.Kom., Khusaeri Andesa, M.Kom., Herwin, M.Kom 


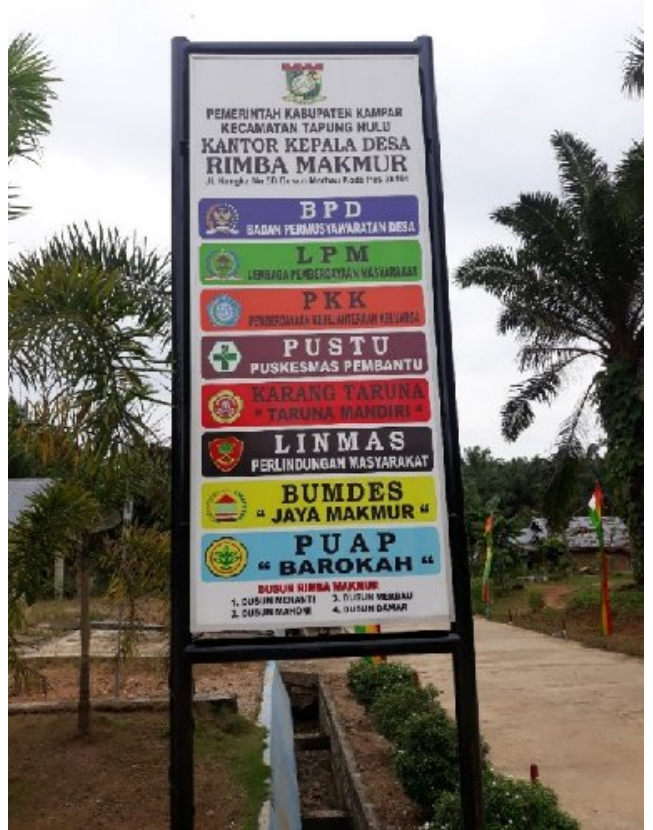

Gambar 3. Plang Desa memuat Unsur Pimpinan Desa

Permasalahan bidang pembukuan keuangan [3], yaitu Bagaimana meningkatkan kemampuan pegawai dalam melakukan pembukuan keuangan. Solusinya adalah difusi inovasi teknologi informasi pengelolaan pembukuan beserta sarana prasarana pendukung yaitu perangkat device dan cara pengelolaan berupa: 1. Perangkat mobile [4], digunakan untuk memberikan layanan eoffice BUMDes Koperasi Simpan Pinjam, 2. Internet [5], digunakan untuk melakukan koneksi dengan data pada cloud computing, 3. Smartphone [6], digunakan oleh masyarakat untuk terhubung dengan BUMDes. Smartphone juga digunakan oleh dua sisi, antara masyarakat dengan pegawai BUMDes dalam berkolaborasi secara langsung, 4. alat cetak [7], digunakan untuk mencetak dokumen. Alat cetak harus tersedia pada area yang aksesibilitas untuk mempermudah masyarakat mencetak dokumen yang diperlukan. Permasalahan bidang tata kelola keuangan [8]: Bagaimana mengimple-mentasikan teknologi informasi untuk melaksanakan tata kelola keuangan. Solusinya adalah: (1) instalasi aplikasi keuangan;

memberikan pelatihan penggunaan aplikasi keuangan KSP; (2) implementasi aplikasi keuangan; (3) pendapingan penggunaan aplikasi. Bidang peningkatan minat masyarakat, yaitu [9] Bagaimana meningkat minat masyarakat untuk meminjam dan menyimpan uang ke Koperasi Simpan Pinjam, solusinya adalah (1) penyamaan pemahaman dalam pemanfaatan teknologi; (2) Implementasi sistem keuangan yang transparan [10]; (2) Pendampingan pelaksanaan sistem keanggotaan.

\section{METODE PENGABDIAN}

Untuk mencapai tujuannya kegiatan PPDM e-Desa Rimba Makmur akan dilakukan melalui beberapa pendekatan [11], antara lain:

1. Model Participatory Rural Appraisal (PRA) yang menekankan keterlibatan masyarakat dalam keseluruhan kegiatan mulai dari perencanaan, pelaksanaan dan evaluasi program kegiatan.

2. Model Participatory Technology Development yang memanfaatkan teknologi tepat guna yang berbasis pada ilmu pengetahuan dan kearifan budaya lokal.

3. Model Community development yaitu pendekatan yang melibatkan masyarakat secara langsung sebagai subyek dan obyek pelaksanaan kegiatan pengabdian kepada masyarakat.

4. Persuasif yaitu pendekatan yang bersifat himbauan dan dukungan tanpa unsur paksaan bagi masyarakat untuk berperan aktif dalam kegiatan ini.

5. Edukatif yaitu pendekatan sosialisasi, pelatihan dan pendampingan sebagai sarana transfer ilmu pengetahuan dan pendidikan untuk pemberdayaan masyarakat.

Secara teknis, pelaksanaan kegiatan PPDM e-Desa Rimba Makmur adalah sebagai berikut: 
1. Persiapan. Pada tahap persiapan ini dilakukan untuk menginventarisasi adanya perubahan kondisi masyarakat khususnya Kelompok BUMDes Jaya Makmur dan Kelompok Karang Taruna Mandiri Desa Rimba Makmur sehingga desain kegiatan yang telah dilakukan dapat memberikan solusi bagi permasalahan mitra. Selain itu di tahap awal ini juga akan dilakukan sosialisasi program secara lebih luas kepada masyarakat dan anggota kelompok BUMDes Jaya Makmur dan Karang Taruna Mandiri.

2. Pelaksanaan kegiatan. Pelaksanaan kegiatan meliputi kegiatan penguatan penguasaan perangkat keras dan perangkat lunak melalui implementasi teknologi, memberikan pelatihan secara bertahap dan berkelanjutan, memberikan pendampingan untuk menjalankan program yang telah di sepakati bersama. Kegiatan penguatan tata kelola organisasi dan kegiatan pengembangan SDM kelompok BUMDes Jaya Makmur dan Kelompok Karang Taruna Mandiri. Pelatihan, workshop dan pendampingan akan dilakukan untuk meningkatkan pengetahuan dan kemampuan sehingga usaha pelayanan yang dikelola dapat berkembang dan berkelanjutan. Pendampingan terus dilakukan untuk kedua kelompok, untuk bersiap mencapai smart economy. Kedua kelompok menerapkan sistem pemasaran berbasis teknologi informasi dengan memanfaatkan perangkat mobile berbasis cloud computing.

3. Evaluasi dan monitoring kegiatan. Evaluasi dan monitoring kegiatan [12] dilakukan secara periodik dengan melibatkan anggota pelaksana dan tokoh masyarakat desa dan bapak kepala Desa Rimba Makmur. Setiap tahun evaluasi akan dilaksanakan secara keseluruhan untuk mengetahui derajat keberhasilan kegiatan berdasarkan target yang telah ditetapkan. Hasil evaluasi tahun pertama akan dijadikan dasar untuk pelaksanaan tahun kedua dan seterusnya.

\section{HASIL DAN PEMBAHASAN}

Dengan adanya kegiatan Program Pengambangan Desa Mitra ini, maka permasalahan utama mitra Desa Rimba Makmur Kecamatan Tapung Hulu, Kabupaten Kampar, Riau pada Kelompok BUMDes dapat meningkat-kan produktivitas masyarakat [13], dan membuka akses masyarakat terhadap sumber pembiayaan melali Koperasi Simpan Pinjam.

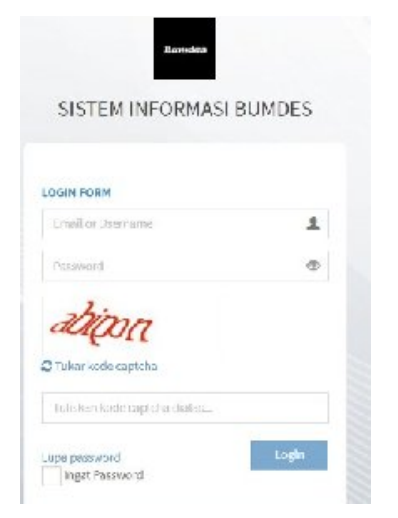

Gambar 4. Lagin masuk ke dalam Aplikasi 


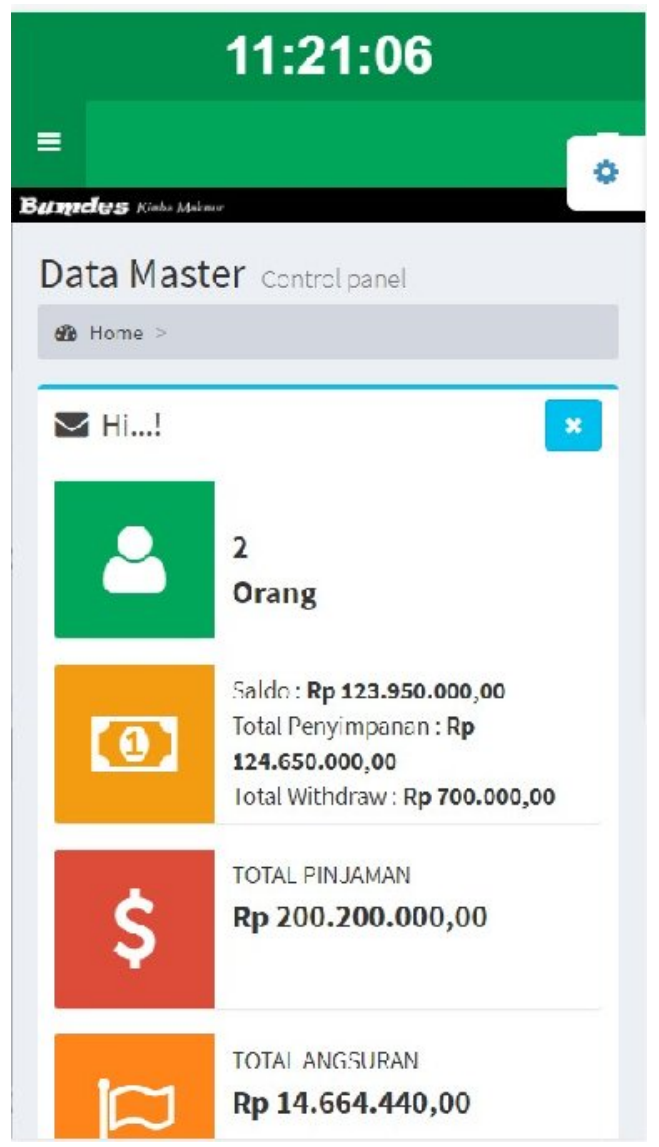

Gambar 5. Data Master Aplikasi

Hasil-hasil kegiatan yang telah dicapai adalah:

1. Pertemuan dengan Direktur BUMDes beserta pegawai telah dilaksanakan, didiskusikan adalah permasalahan yang dihadapi oleh warga, penentuan cara pengelolaan keungan berbasis aplikasi, domain BUMDes, akses informasi, dan layanan yang dapat di akses masyarakat secara langsung serta cara merespon nasabah. Berdasarkan kesepakatan domain BUMDes adalah bumdes.desarimbamakmur. desa.id. Adapun website ditempatkan menggunakan jasa webhosting untuk setiap periode tahun.

2. Pertemuan dengan Ketua Karang Taruna telah dilaksanakan, didiskusikan adalah permasalahan yang dihadapi dalam meningkatkan produktifitas anggota Karang Taruna, perakitan perangat GPS untuk kelompok Lembu Sawit, melakukan pendampingan untuk alih teknologi. Berdasarkan kesepakatan, Karang Taruna akan memenuhi kebutuhan GPS yang diperlukan oleh Kelompok Lembu Sawit.

Domainbumdesrimbamakmur.desa.id, memiliki fasilitas mencakup:

1. Informasi terkini tentang program BUMDes, kegiatan, perkembangan terbaru, dan informasi lainnya yang relevan.

2. Masyarakat yang akan melakukan transaksi dapat melakukan melalui perangkat online.

3. Masyarakat dapat berinteraksi untuk bertransaksi dengan BUMDes, selanjutnya pegawai langsung memverifikasi untuk di laksanakan.

4. Tersedia link untuk memperoleh informasi produk yang dihasilkan BUMDes.

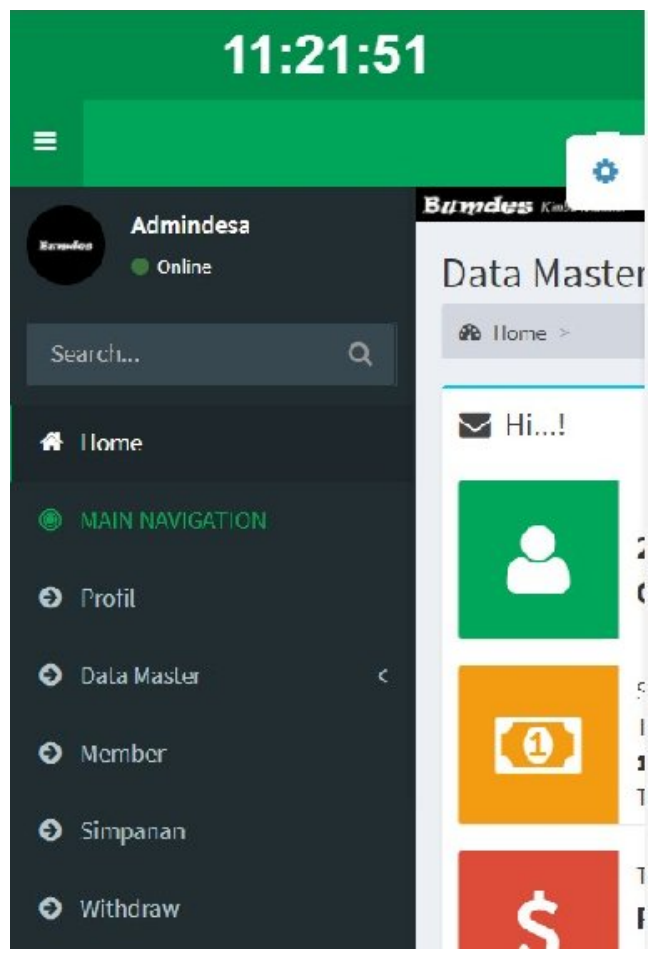

Gambar 6. Daftar Menu

\section{SIMPULAN}

Pelaksanaan Kegiatan Program Pengembangan Desa Mitra e-Desa Rimba 
Makmur Kecamatan Tapung Hulu Kabupaten Kampar Provinsi Riau telah dilaksanakan dengan beberapa tahapan kegiatan, dimulai dari kunjungan pendahuluan kepada masing-masing kelompok sasaran, menyepakati masalah dan solusi yang akan diterapkan, merangkai perangkat keras dan perangkat lunak, dan melakukan uji coba. Secara umum dapat disimpulkan bahwa:

1. Antusias masyarakat dalam mengikuti tahapan kegiatan pada pelatihan perakitan GPS maupun penerapan teknologi pada BUMDes Jaya Makmur

2. Terjadi peningkatan pengetahuan dan ketrampilan mitra dalam penggelolaan administrasi desa berbasis teknologi informasi maupun dalam penggunakan teknologi dalam pemantauan sebaran sapi.

3. Dalam akses internet sudah tersedia signal GSM pada tingkat $3 \mathrm{G}$, sudah cukup mumpuni untuk mengakses layanan di BUMDes dan media pelatihan bagi Karang Taruna Mandiri.

Kelompok masyarakat sasaran adalah

Desa Rimba Makmur yang memiliki tingkat pengetahuan dan kemampuan ekonomi yang beragam dengan sebaran geografis relatif luas. Oleh karena itu, saran yang dapat disampaikan:

1. Adanya kebijakan pemerintah yang lebih flexible dalam pelaksanaan pengabdian sehubungan dengan bencana nasional COVID-19

2. Membuat display informasi BUMDes pada tempat-tempat umum.

3. Menyediakan akses secara Internet Desa secara gratis dan merata di seluruh Desa Rimba Makmur.

4. Perhatian dari pihak-pihak terkait baik dari pemerintah maupun swasta dalam upaya meningkatkan pengetahuan dan ketrampilan masyarakat.

5. Upaya-upaya seperti pelatihan, penyuluhan, dan pendampingan sangat dibutuhkan bagi mereka dalam rangka meningkatkan pengetahuan dan ketrampilan.

\section{UCAPAN TERIMAKASIH}

Terimakasih kepada Kementerian Riset dan Teknologi/Badan Riset dan Inovasi Nasional telah mendanai penelitian ini. Lembaga Penelitian dan Pengabdian STMIK Amik Riau, STMIK Amik Riau yang telah melakukan pemantauan, mengingatkan dan selalu berdiskusi tentant keberjanjutan pelaksanaan PPDM

\section{DAFTAR PUSTAKA}

[1] D. T. R. I. Peraturan Menteri Desa, Pembangunan Daerah Tertinggal, "Peraturan Menteri Desa, Pembangunan Daerah Tertinggal, Dan Transmigrasi Republik Indonesia," J. Chem. Inf. Model., vol. 53, no. 9, pp. 1689-1699, 2013, doi:

10.1017/CBO9781107415324.004.

[2] PM Koperasi dan UMKM RI No. 13/Per/M.KUKM/IX/2015,

"Peraturan Menteri Koperasi dan Usaha Kecil dan Menengah Republik Indonesia Nomor 13/Per/M.KUKM/IX/2015 Tentang Pedoman Akuntansi Usaha Simpan Pinjam Oleh Koperasi," 2015.

[3] I. G. P. F. P. Sudhana, I. K. Suwintana, A. D. Yulianthi, and I. G. A. O. Sudiadnyani, "Pengembangan Aplikasi Internet Banking Koperasi Simpan Pinjam Berbasis Web," Matrix J. Manaj. Teknol. dan Inform., vol. 9, no. 3, pp. 89-95, 2019, doi: 10.31940/matrix.v9i3.1355.

[4] A. Prayitna and F. X. H. Nugroho, "Model Pengembangan Sistem Informasi Berbasis Technology Acceptance Model Dan Technology Ajax Pada Koperasi Simpan Pinjam," J. Teknol. Informasi-Aiti, vol. 14, no. November, pp. 31-42, 2017.

[5] M. Puncak, D. A. N. Kemampuan, and P. Terhadap, "Pengaruh 
Pemanfaatan Teknologi, Partisipasi Pemakai, Manajemen Puncak Dan Kemampuan Pemakai Terhadap Efektivitas Sistem Informasi Akuntansi," E-Jurnal Akunt., vol. 19, pp. 2234-2261, 2017.

[6] Dani Anggoro, M. D. Umar, E. Vinanty, and D. Dananjaya, "Rancangan Sistem Informasi Koperasi Simpan Pinjam Guru Dan Pegawai Pada Koperasi Smk Manggala Tangerang," Semin. Nas. Teknol. Inf. dan Komun. 2015 (SENTIKA 2015) Yogyakarta, 28 Maret 2015, vol. 2015, no. Sentika, pp. 213-222, 2015.

[7] P. Penyusunan et al., "Prosedur Penyusunan Laporan Keuangan Unit Simpan Pinjam Koperasi Pegawai "Satria Batara" P T. Bank BTN (Persero) Cabang Purwokerto," vol. 2, no. 1, pp. 6981, 2009.

[8] T. Djitaningsih, "Akuntansi untuk Koperasi Simpan Pinjam Unit Simpan Pinjam Koperasi Konvensional," 2008.

[9] I. G. T. Isa and G. P. Hartawan, "Perancangan Aplikasi Koperasi Simpan Pinjam Berbasis Web (Studi," J. Ilm. Ilmu Ekon., vol. 5, no. 10, pp. 139-151, 2017.

[10] Y. Ramdhani and R. Lantin, "Sistem Informasi Simpan Pinjam Berbasis Website Koperasi 'RikRik Gemi' SMKN 15 BANDUNG," Informatika, vol. 3, no. September, pp. 183-190, 2016.

[11] Y. Chrismardani, "Model Pembelajaran Kewirausahaan Yang Berkelanjutan," Eco-Entrepreneur, vol. 2, no. 1, pp. 106-119, 2016.

[12] H. T. Hinggo S et al., "Pelatihan Manajemen Pemasaran Dan Strategi Pada Guru Dan Siswa Sma Negeri 13 Pekanbaru," J. Pengabdi. UntukMu NegeRI, vol. 2, no. 2, pp. 28-34, 2018, doi: 10.37859/jpumri.v2i2.839.

[13] N. R. Yuliani, "Penyuluhan
Kewirausahaan Bagi Kelompok Umkm Guna Meningkatkan Motivasi Dalam Berwirausaha," $J$. Pengabdi. UntukMu NegeRI, vol. 4, no. 1, pp. 84-87, 2020, doi: 10.37859/jpumri.v4i1.1884. 